\title{
Dias de glória: uma análise sobre o triplo triunfo de Otaviano, em 29 a.C.
}

\author{
Days of glory: an analysis of Octavian's triple triumph in 29 B.C.
}

Macsuelber de Cássio Barros da Cunha*

\begin{abstract}
Resumo: Em agosto de 29 a.C., Roma foi palco de um grandioso acontecimento. Trata-se do triplo triunfo de Otaviano. Cerimônia que exaltou as vitórias do Imperator Caesar e de suas tropas e exibiu as riquezas daí advindas. A procissão triunfal ligava passado, presente e futuro, pois se vinculava, em sua origem, com o fundador de Roma e primeiro triunfador, Rômulo; festejava no momento presente as vitórias do general triunfante, exibindo os povos vencidos e as riquezas trazidas; e inscrevia o nome do triunfador na memória das futuras gerações, tanto pelo feito realizado, quanto pelo triunfo memorável que percorreu as ruas de Roma, como também pelos monumentos e/ou edifícios que poderiam ser erguidos com as riquezas trazidas. Neste artigo, fazemos uma análise sobre este grandioso acontecimento e suas relações com a arquitetura e com a memória.
\end{abstract}

\begin{abstract}
In August of $29 \mathrm{BC}$, Rome witnessed a great event, the triumph of Octavian. A ceremony that exalted the victories of the Imperator Caesar and of his troops and exhibited the conquered riches. The triumphal procession linked past, present, and future. It was connected, in its origin, with the founder of Rome and first triumphator, Romulus; it celebrated in the present moment the victories of the triumphator general, exhibiting the vanquished peoples and the riches brought as war booty; and inscribed the name of the victor in the memory of future generations, both for the achievement, and for the memorable triumph that went through the streets of Rome, as well as for the monuments and / or buildings that could be erected with the war booty. In this work we analyze this great event and its relations with the architecture and the memory.
\end{abstract}

\section{Palavras-chave:} Triplo Triunfo. Otaviano. Arquitetura. Memória.

\section{Keywords:}

Triple Triumph. Octavian. Architecture. Memory. 
ualquer um que chegasse a Roma no fim do primeiro século a.C. se surpreenderia com a grandiosidade da cidade, com a beleza arquitetônica e com a monumentalidade adquirida ao longo de séculos de história. Algumas de suas importantes construções remontavam, de acordo com as tradições romanas, ao período da realeza e contribuíam para a grandeza de Roma, servindo de suporte para o desenvolvimento de seu poder e expansão territorial.

A grandiosa muralha, ${ }^{1}$ que cercava as sete colinas, tinha sua origem ligada ao sexto rei de Roma, Sérvio Túlio. Tal muralha possuía uma importância não apenas no que se refere à defesa da cidade, como também uma importância religiosa, visto que a muralha, de acordo com o rito etrusco, deveria acompanhar o traçado do pomerium, ${ }^{2}$ delimitando as fronteiras sagradas da cidade. A primeira muralha de Roma teria sido construída pelo fundador e primeiro rei de Roma, Rômulo, cercando o monte Palatino, lugar de fundação de Roma.

A Cloaca Máxima, que drenava uma grande área da cidade, teria sido iniciada por Tarquínio, o Antigo e terminada por Tarquínio, o Soberbo. ${ }^{3}$ Era objeto de grande admiração pelo seu tamanho, tão grande que os homens podiam atravessá-la em barcos, e pela força de suas paredes, que resistiam às mais violentas tempestades e até inundações quando a água recuava em seu canal.

Importantes templos, como o de Vesta, que abrigava o fogo sagrado de Roma, e o templo de Janus, tinham sua origem relacionada com o segundo rei de Roma, Numa Pompílio.

Além disso, quem chegasse a Roma se impressionaria com a grande movimentação e com os edifícios públicos dispostos no Forum Romanum, coração da cidade; ou com as estradas pavimentadas, potente declaração do poder romano sobre as paisagens conquistadas; ou ainda com os inúmeros aquedutos, que traziam água potável para Roma.

Além disso, fora das muralhas servianas ficava o Campo de Marte, onde figurava, além de diversos templos e outros edifícios públicos, o majestoso teatro de Pompeu, o primeiro teatro de pedra permanente em Roma, que impressionava pela grandiosidade e beleza da construção.

\footnotetext{
${ }^{1}$ Apesar de tradicionalmente a muralha se relacionar ao rei Sérvio Túlio, século VI a.C., a partir dos vestígios arqueológicos do que sobrou da muralha, sabe-se que a muralha data do século IV a.C, pois a pedra utilizada (Grotta Oscura) veio das pedreiras de Veii, cidade etrusca conquistada por Roma em 396 a.C. Uma das hipóteses é que a muralha serviana tenha sido reconstruída no século IV a.C. após a invasão de Roma pelos gauleses em 390 a.C.

${ }^{2}$ O pomerium dermarcava os contornos sagrados da cidade e delimitava as fronteiras religiosas e jurídicas. No caso de Roma, a muralha não acompanhava a linha do pomerium em toda sua extensão, pois sabe-se que o Aventino ficava dentro das muralhas, mas fora do pomerium, pelo menos até o período de Cláudio.

${ }^{3}$ Respectivamente o quinto e sétimo reis de Roma.
} 
Vemos assim que, ao longo de sua história, iniciando com a Realeza e perpassando todo o período da República, Roma serviu de suporte para importantes construções e monumentos arquitetônicos que impressionaria quem os visse, mas foi no fim do I século a.C. que Roma foi ganhando maior grandiosidade arquitetônica e monumentalidade. De acordo com Valerie Hope (2005, p. 65):

Foi durante o primeiro século antes de Cristo, contudo, e nas mãos de proeminentes homens como Sula, Pompeu e Júlio César, que a cidade cada vez mais ganhou os símbolos físicos de poder. Competição aristocrática encorajou tais homens a embelezar Roma como um meio de aumentar seu próprio prestígio.

Voltamos a dizer, portanto, que qualquer um que chegasse a Roma no fim do primeiro século a.C. se surpreenderia com a grandiosidade da cidade, com a beleza arquitetônica e com a monumentalidade adquirida ao longo de séculos de história; no entanto, aquele que chegasse na primeira quinzena do mês de agosto de 29 a.C. ficaria muito mais surpreso e encantado, pois, neste período, a cidade fervilhava em preparativos para um dos rituais mais importantes que poderiam acontecer, um triunfo.

Tratava-se da volta do general vitorioso Caio Júlio César Otaviano, ${ }^{4}$ que regressava à Roma após sua vitória contra o Egito no ano anterior. A cidade se preparava para a celebração de seu triplo triunfo sobre Dalmácia (35-33 a.C.), Ácio (31 a.C.) e Egito (30 a.C.). Para tal comemoração, diversos pontos da cidade devem ter recebido decoração adequada, como a tradição mandava, mesmo porque uma procissão triunfal constituía um importante momento, uma festividade memorável para todos aqueles que dela tomavam parte. Assim:

O triunfo - um elaborado ritual celebrando vitórias militares de Roma sobre povos estrangeiros - era uma das mais importantes instituições da Roma antiga, um ritual ao mesmo tempo religioso e político, militar e espetacular. Uma das maiores honras que um homem romano poderia alcançar, o triunfo atravessou a cidade de Roma do início da República até os períodos imperiais. O triunfo era uma instituição quintessencialmente romana, incorporando aspectos fundamentais da visão evolutiva que Roma tinha de si mesma em termos de força militar e domínio mundial (POPKIN, 2016, p. 2).

\footnotetext{
${ }^{4}$ O jovem Gaius Otauius Turinus adotou o nome de Gaius Julius Caesar após a morte de seu pai adotivo, Júlio César. De acordo com Scott-Kilvert (1987, p. 32, apud SILVA, 2014, p. 23), como, em 44 a.C., Otávio passou a adotar o mesmo nome de seu pai adotivo, alguns historiadores optaram por chamá-lo nesse período como Otaviano, com o propósito de diferenciação, embora o futuro princeps nunca tenha usado esse nome para si. No entanto, nos utilizamos do nome Otaviano para tratar dos acontecimentos de 29 a.C., visto que somente em 27 a.C. ele passa a ser chamado de Augusto.
} 
De acordo com a tradição romana, os triunfos se ligavam, em sua origem, com Rômulo. ${ }^{5}$ Segundo Dionísio de Halicarnasso (Antiquitates Romanae, II, 34), contemporâneo de Otaviano, Rômulo teria sido responsável pela instituição de triunfos em Roma, ao realizar a primeira procissão triunfal:

O próprio Rômulo veio por último na procissão, vestido com um manto púpura e com uma coroa de louro sobre a cabeça, e para manter a dignidade real, ele andou numa quadriga. $O$ resto do exército, tanto a pé quanto a cavalo, seguiu, alinhado em suas várias divisões, louvando os deuses nas canções de sua pátria e exaltando seu general em versos improvisados. [...] Tal foi a procissão vitoriosa, marcada pelo carregamento de troféus e concluindo com um sacrifício, que os romanos chamam de triunfo, que foi instituída pela primeira vez por Rômulo. Mas, em nossos dias, o triunfo tornou-se um espetáculo muito oneroso e ostentoso, sendo atendido por uma pompa teatral que é projetada mais como uma demonstração de riqueza do que como aprovação de valor, e saiu em todos os aspectos da sua antiga simplicidade.

É interessante observar que muitos dos aspectos atribuídos ao primeiro triunfo realizado por Rômulo eram características marcantes nos triunfos realizados tanto durante a República quanto durante o Principado, de modo que podemos perceber a crença romana na continuidade de aspectos importantes relacionados à procissão triunfal bem como sua ligação com o passado de Roma e com seu fundador, embora possamos perceber também, na fala de Dionísio de Halicarnasso, seu desagrado com relação a alguns aspectos presentes nos triunfos de seu tempo, como, por exemplo, a teatralidade, excesso de gastos e ostentação. Tratamos sobre alguns destes aspectos mais à frente.

O triplo triunfo de Otaviano dava continuidade a esta tradição romana, que se ligava a Rômulo, valorizava e ressaltava as vitórias militares sobre os povos estrangeiros, engrandecendo e concedendo enorme prestígio ao general vitorioso, bem como dignificando e enaltecendo o solo romano, palco desta grandiosa celebração. Este último aspecto era de suma importância para o imaginário romano, que relacionava os triunfos com a glorificação de Roma e seu solo sagrado, sendo muito mal visto, ou visto de modo inferior, os triunfos realizados fora de Roma. ${ }^{6}$ Favro $(1994$, p. 152$)$ ressalta isso ao afirmar que:

O triunfo estava fortemente ligado à cidade como uma necessidade cosmológica e política. Não importa quão longe a autoridade romana se estendeu, a cidade

\footnotetext{
${ }^{5}$ Para Tito Lívio (Ab Urbe Condita, I, 38, 3), seguido por Eutrópio (Breviarium historiae Romanae, I, 6, 1), o primeiro triunfador foi Tarquínio, o Antigo (TARPIN, 2009, p. 131).

${ }^{6}$ Podemos citar, por exemplo, a cerimônia realizada por Marco Antônio em Alexandria para comemorar a vitória sobre a Armênia. Tal cerimônia foi vista como um triunfo fora de Roma e foi utilizada por Otaviano e seu grupo de apoio como propaganda negativa contra Marco Antônio.
} 
no Tibre permaneceu o ponto focal do poder. Roma era a fonte da romanitas e a casa de Júpiter Optimus Maximus, para quem todo triunfo era dedicado.

O triplo triunfo de Otaviano, realizado em Roma, vinha ao encontro do enorme desagrado que causou ao povo romano o fato de Marco Antônio ter realizado, em Alexandria, uma espécie de procissão triunfal, em 34 a.C., em comemoração à vitória sobre a Armênia, fato este que foi propagandeado por Otaviano a seu favor, ao passo que denegria a imagem de Marco Antônio.

O triplo triunfo de Otaviano, em 29 a.C., ocorreu em três dias consecutivos, de 13 a 15 de agosto, de modo que o primeiro dia comemorava a vitória sobre a Dalmácia, o segundo dia a vitória em Ácio e o terceiro dia a vitória sobre Alexandria (Dion Cássio, Historia Romana, LI, 21; Suetônio, De Vita Caesarum, Diuus Augustus, XXII). Não se sabe como se desenrolou a procissão ao longo dos três dias, nem se Otaviano participou da mesma forma nos três dias, ${ }^{7}$ mas, apesar de não termos informações mais detalhadas sobre o triplo triunfo de Otaviano, ${ }^{8}$ podemos inferir algumas de suas principais características, já que muitas das etapas da procissão triunfal estavam ancoradas na tradição e, sendo assim, deveriam seguir certas regras, das quais passamos a tratar a seguir.

Para começar, o triunfo sempre se iniciava no Campo de Marte, ou seja, fora do pomerium, já que o Campo de Marte era tradicionalmente dedicado ao deus da guerra, de tal forma que o general vitorioso não poderia entrar no pomerium investido do imperium ${ }^{9}$ que recebera antes de deixar Roma rumo ao campo de batalha. Isso se dava, pois o pomerium, além de fronteiras religiosas, delimitava também fronteiras jurídicas, no que diz respeito à separação do domínio dos magistrados com imperium, poder de comando militar que não poderia ser usado dentro do pomerium. Mesmo com as mudanças ocorridas durante o Principado, os imperadores, em seus triunfos, iniciavam a procissão triunfal no Campo de Marte, ou seja, fora do pomerium. ${ }^{10}$ Sobre este aspecto, Beard (2007, p. 205) afirma que:

\footnotetext{
${ }^{7}$ Baseando-se em Dion Cássio e Sérvio, Carsten H. Lange (2009, p. 152) acredita ser bem possível que Otaviano tenha entrado apenas no último dia, já que não era aceitável que os 700 senadores entrassem em Roma em procissão duas vezes e porque teria causado muito mais impacto entrar no último dia, também como sinal de moderação.

${ }^{8}$ Segundo Michel Tarpin (2009, p. 136), "o texto de Dion, que é o testemunho indireto mais completo, realmente não diz muito. Suetônio se contenta em plagiar as Res Gestae separando as duas ovações e os três triunfos curules. A periocha 135 de Tito Lívio é ainda mais curta".

${ }^{9}$ Segundo Paulo Martins (2011, p. 49-50), de modo geral, imperium designa poder soberano, como o do pater familias ou o de um general; "o imperium nasce e confunde-se com as próprias magistraturas e é, dessa maneira, que as encontramos cum imperio e sine imperio, ou seja, aquelas que possuíam uma gama de poderes".

${ }^{10} \mathrm{O}$ que pode ser visto a partir dos relatos de Flávio Josefo, no livro sete de sua obra De Bello Judaico, que, dentre outros assuntos, trata sobre o triunfo de Vespasiano e Tito, em 71, sobre os judeus.
} 
A cerimônia de triunfo não era meramente uma extraordinária marca pública de honra para um comandante; ela também envolveu a entrada em Roma de um general à frente de suas tropas. Isso quebrou todos os principais pressupostos culturais da vida romana que insistiam na divisão entre a esfera da atividade civil e militar e que eram a base de muitas das sutilezas legais que surgiram em torno da ideia do pomerium ou imperium.

De tal forma que, durante a República, ao retornar a Roma, o general vitorioso que queria realizar um triunfo convocaria o Senado para fora do pomerium, para receber a autorização necessária. Se a reivindicação fosse aceita, o Senado então organizava uma assembleia do povo, que deveria conceder formalmente ao general triunfante o imperium dentro do pomerium no dia da sua celebração (BEARD, 2007, p. 201-202).

A partir do Campo de Marte, adentrando o pomerium, o general triunfante à frente de sua tropa iniciava seu triunfo, passando por diversos lugares antes de chegar ao objetivo final, que era o templo de Júpiter, no monte Capitolino, onde os sacrifícios seriam realizados. Sobre esse caminho que a procissão percorria, apesar das variações, pode-se traçar uma rota provável ao longo da cidade, ${ }^{11}$ partindo do Campo de Marte, numa área próxima ao Circo Flamínio, passando pelo Forum Holitorium, pelo Velabrum e pelo Forum Boarium, seguindo pelo Circo Máximo, contornando o monte Palatino, atravessando por dentro do Fórum Romano e indo em direção ao monte Capitolino, o destino final da procissão (POPKIN, 2016, p. 07; FAVRO, 1994, p. 154). Tal rota pode ser visualizada no mapa abaixo (Figura 1), que contém o traçado desta provável rota triunfal.

No entanto, "não podemos mapear com certeza a rota de qualquer procissão triunfal individual; menos ainda podemos reconstruir "a" rota triunfal ou até mesmo ter certeza de que tal coisa existia" (BEARD, 2007, p. 104). De todo o roteiro desta provável rota triunfal, por onde deve ter passado a procissão de Otaviano, três pontos são certos: a saída no Campo de Marte, o contorno do Palatino e o término no Capitolino, já que, como afirma Favro (1994, p. 156), estes três componentes são constantes em todas as procissões.

É necessário ressaltar a grande importância que as construções e monumentos desempenhavam no que se refere à rota triunfal, na medida em que o general triunfante poderia escolher passar por determinados monumentos que tivessem ligação com o seu nome ou com o nome de sua família, ressaltando seus feitos passados ou enaltecendo uma memória positiva de si mesmo. Sendo assim, podemos supor que a procissão de Otaviano, ao sair do Campo de Marte, passou próximo do local onde César tinha

\footnotetext{
${ }_{11}$ Mary Beard (2007, p. 101) esclarece que: "Essencialmente, o método que foi adotado no rastreamento da rota é o de conectar os pontos, ou seja, traçar todas as dispersas referências topográficas a pontos em qualquer procissão triunfal, em qualquer período e em qualquer autor, e depois desenhar uma linha entre eles, partindo do pressuposto de que o triunfo tomou uma única rota ortodoxa ao longo da história romana, apesar da mudança dos monumentos da cidade e de outros prédios novos".
} 
iniciado a construção de um teatro, que o próprio Otaviano concluiria anos mais tarde, o Teatro de Marcelo; contornando o Palatino, onde poderia ser visto o esplêndido templo de Apolo, construído por Otaviano e que seria consagrado no ano seguinte; passando pelo Fórum Romano, ao lado de importantes edifícios como o Templo do Divino César, iniciado na época do triunvirato, a Cúria e a Basílica Júlia, ambas concluídas por Otaviano, bem como a nova rostra construída por ele, edifícios estes que seriam consagrados poucos dias após o triunfo.

Figura 1 - Diagrama da rota triunfal

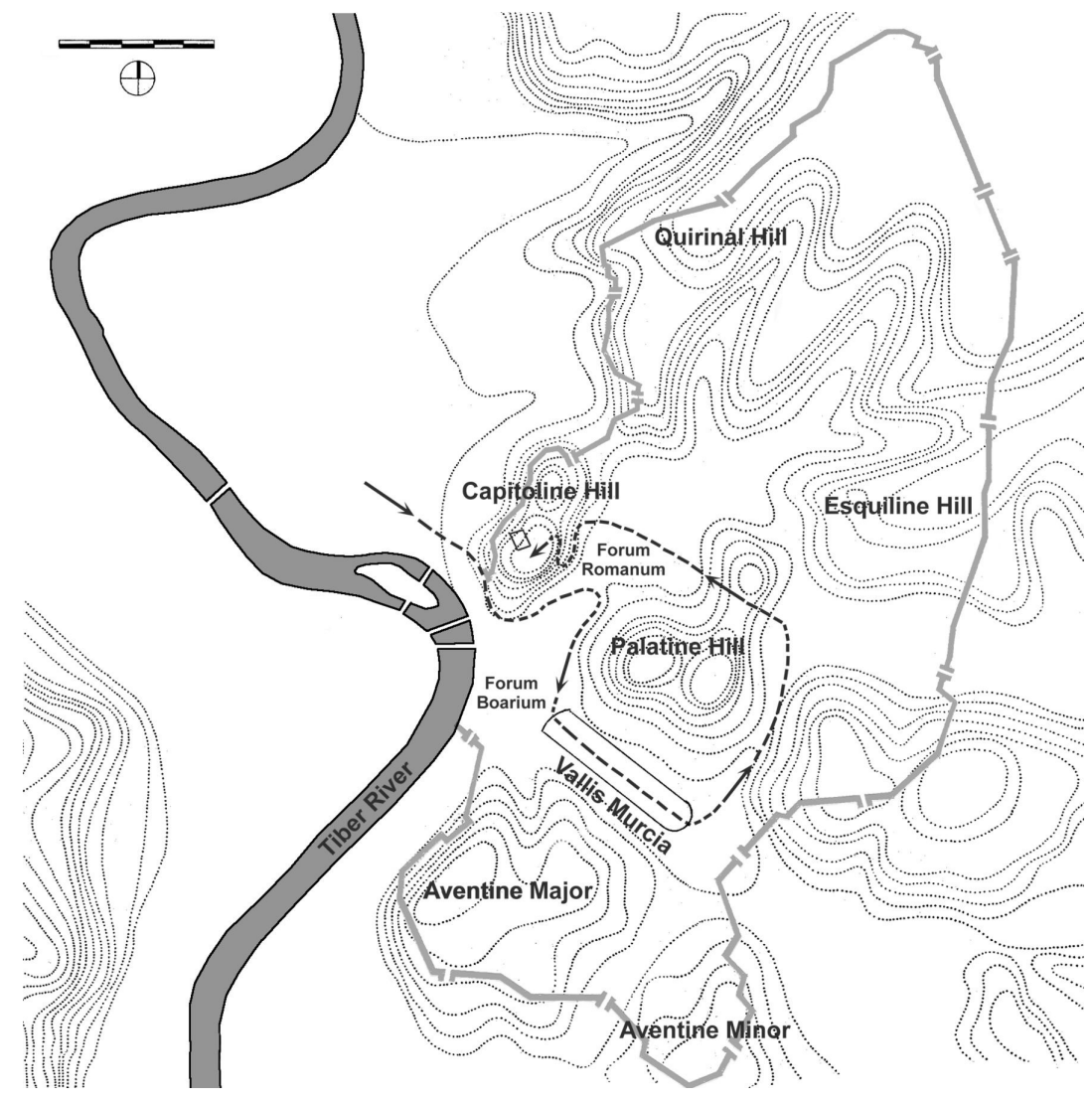

Fonte: Favro e Johanson (2010, p. 15).

Tais edifícios e monumentos exaltavam a imagem de Otaviano e demonstravam sua preocupação com a melhoria arquitetônica da cidade, engrandecendo-a e tornando-a digna de ser a capital do mundo conhecido.

O triunfo é muitas vezes postulado como definindo de alguma forma a memória romana ou inscrevendo a memória na paisagem urbana romana. Pode-se comumente entender que os monumentos serviam como repositórios para a memória dos triunfos (POPKIN, 2016, p. 10). 
Esta memória que ficava registrada nos monumentos, de certo modo, perpetuava o nome por trás de tais construções, mantendo seu nome vivo na memória dos vindouros e conferindo-Ihe prestígio e glória. Desta forma, a procissão triunfal ligava passado, presente e futuro, pois se ligava, em sua origem, com o fundador de Roma e primeiro triunfador, Rômulo, passando também por monumentos e edifícios construídos por triunfadores do passado com o dinheiro trazido dos povos vencidos; festejava, no momento presente, as vitórias do general triunfante, exibindo os povos vencidos e as riquezas trazidas com a vitória, comemorando-a com grande pompa e luxo; e inscrevia o nome do triunfador na memória das futuras gerações, tanto pelo feito realizado quanto pelo triunfo memorável que percorreu as ruas de Roma, como também pelos monumentos e/ou edifícios que poderiam ser erguidos com as riquezas trazidas como espólio de guerra.

[...] cada passo [do triunfo] se baseou na história topográfica da cidade. [...] Cada procissão era parte de um continuum urbano, uma rua conectada no tempo e no espaço com o passado e o futuro do Estado romano, do ritual de triunfo e da topografia de Roma (FAVRO, 1994, p. 155).

Ainda com relação aos monumentos ligados ao triunfo, não podemos deixar de tratar aqui dos arcos triunfais. ${ }^{12}$ Arcos monumentais que serviam de passagem para as procissões triunfais, bem como serviam de memorial para estes mesmos triunfos, contendo esculturas e relevos relacionados ao tema. Tais construções, assim como outras importantes construções que se perderam ao longo dos anos, das quais nada nos chegou, podem ser melhor estudadas a partir de suas representações cunhadas em moedas do período, moedas estas que muito nos auxiliam no estudo de aspectos da sociedade e da cultura antigas, como, por exemplo, no estudo da arquitetura romana.

No que se refere às moedas, devemos lembrar que cada vez mais ela se tornou um instrumento de propaganda, transmitindo determinada imagem ou mensagem referente àquele a quem a moeda se referia, pois, a partir de 44 a.C., o Senado autorizou que Júlio César tivesse sua face representada nas moedas, algo até então inédito, de modo que César se aproveitou "de uma medida de cunho essencialmente econômico para marcar sua imagem em todos os territórios governados por Roma" (MARTINS, 2011, p. 52). Deste modo, a partir de César, os líderes romanos passaram a representar não somente símbolos e inscrições, mas também suas faces no anverso ou reverso das moedas; na

\footnotetext{
12 De acordo com Richardson (1992, p. 20), apesar de Plínio dizer que o arco era usado, assim como a coluna, para levantar as estátuas acima dos mortais, isto é, uma forma arquitetônica que era essencialmente uma base para a estatuária que carregava, deve-se duvidar disso devido ao seu caráter de passagem e/ou entrada que deve ter sido sempre fortemente sentido e pelo fato de ter sido usado originalmente como um memorial para um triunfo.
} 
época do Triunvirato, Marco Antônio, Lépido e Otaviano passaram a cunhar moedas de modo autônomo, sem o aval do Senado (MATINGLY, 1971, p. 17, apud SILVA, 2014, p. 64). Após a vitória de Otaviano em Ácio, as moedas cunhadas fizeram alusão direta ou indireta ao vitorioso triunfador Otaviano, propagandeando seu nome e seus feitos.

\begin{abstract}
A cunhagem de moedas era uma expressão da soberania política, por isso nenhuma cunhagem poderia ser executada sem uma referência epigráfica ou iconográfica ao Imperador, sendo esta referência considerada obrigatória, pois a efígie imperial identificava o próprio Estado romano e, por conseguinte, era a identificação do povo romano e de sua soberania. A iconografia imperial nas moedas deve ser considerada um documento oficial. Nas moedas, podemos perceber concepções de poder professadas pelos soberanos, programas evergéticos, suas vitórias militares e suas ambições dinásticas. A informação veiculada pelas moedas dependia frequentemente de seu conteúdo metálico e da qualidade de seus destinatários habituais (ZEHNACKER, 1987, p. 321-325, apud GONÇALVES, 2013, p. 57).
\end{abstract}

A partir desta perspectiva, nos utilizamos de algumas moedas ao longo de nosso trabalho, pois acreditamos que elas nos auxiliam na compreensão de alguns dos acontecimentos referentes ao período, na percepção das representações criadas e propagadas para ressaltar uma imagem positiva de Otaviano, bem como nos auxiliam na visualização de determinadas obras arquitetônicas, das quais não temos suficientes dados arqueológicos.

No que se refere aos arcos triunfais, tal aspecto pode ser mais bem compreendido no que se refere ao triplo triunfo de Otaviano, pois, de acordo com Dion Cássio (Dio Cass., Hist. Rom., LI, 19), no ano de 30 a.C., após a vitória de Otaviano sobre Alexandria, foi decidido em Roma a construção de um arco decorado com troféus em Brundisium (atual Bríndisi) e outro no Fórum Romano.

Não se sabe com certeza a localização deste arco no Fórum Romano e os autores divergem quanto a isso, de modo que alguns chegam mesmo a duvidar se tal arco foi realmente construído, pois sabemos que ele foi votado pelo Senado, mas não temos referências sobre sua consagração. Outros autores acreditam que ele foi construído entre o templo de César e o templo de Castor e Pólux, mas que teria dado lugar, dez anos mais tarde, ao arco triplo em homenagem à volta dos estandartes que estavam em poder dos partos. Há quem defenda que o arco de 29 a.C. estaria de um lado do templo de César e o arco de 19 a.C. ocuparia o outro lado do templo. ${ }^{13}$

\footnotetext{
${ }^{13}$ Holland (1946, p. 52-59), em seu trabalho The Triple Arch of Augustus, trata de modo resumido sobre estes diversos autores e suas teorias no que se refere a estes dois arcos que teriam sido erguidos no Fórum. Outro autor que trata sobre os estudos dos diversos autores que abordaram a temática sobre os arcos de Augusto é Kleiner (1989, p. 195206), em seu texto The study of Roman triumphal and honorary arches 50 years after Kähler.
} 
Um vestígio que é visto por alguns estudiosos como comprovação da existência deste arco triunfal próximo ao templo de César é um bloco de mármore de mais de 2 metros de comprimento, encontrado no século $\mathrm{XVI}$, contendo uma inscrição, ${ }^{14} \mathrm{com}$ um decreto de honras públicas para Otaviano e uma data consular de 29 a.C. (RICHARDSON, 1992, p. 27; HOLLAND, 1946, p. 55).

No entanto, apesar de não sabermos a localização exata deste arco, sabemos que tratava-se de um arco simples, ou seja, com apenas uma passagem (diferente do arco triplo erguido em 19 a.C.) e era coroado por uma escultura de Otaviano em uma quadriga. Tais informações podem ser obtidas, como dissemos antes, a partir de moedas do período, pois o arco é representado em moedas cunhadas na época do triplo triunfo de Otaviano ou um pouco depois (29-27 a.C.). Trata-se de um denário cunhado provavelmente em Roma que traz, no reverso, o desenho de um arco simples, cujo topo contém a imagem de Otaviano numa quadriga triunfal e abaixo da quadriga pode-se ver a inscrição IMP CAESAR na arquitrave do arco. O anverso traz a efígie de Otaviano (RIC I 267, Figura 2).

Figura 2 - Moeda de Prata. Denário. RIC I 267
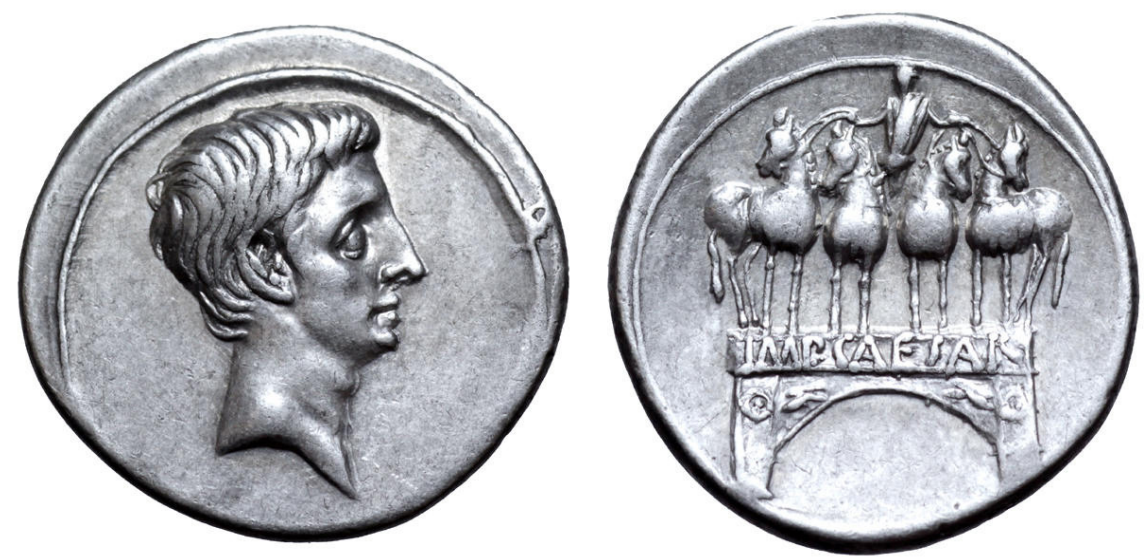

Fonte: https://www.numisbids.com/n.php?p=lot\&sid=1884\&lot=723. Acesso em: 29 jul. 2017.

Estas moedas demonstram a importância que tais monumentos possuíam na sociedade antiga, servindo como um memorial do grande acontecimento do qual se tratava o triunfo, mantendo vivos, na memória das pessoas, os feitos de Otaviano e as vitórias alcançadas por ele. Além disso, as próprias moedas eram utilizadas para propagar estes feitos e perpetuar a memória deles, através da representação dos monumentos arquitetônicos que comemoravam e lembravam tais eventos ou de outras imagens relacionadas a eles, como vemos mais à frente. As moedas serviram como importante

14 "Senatus populusque Romanus/Imp. Caesari diui Juli f. cos. quinct./cos. design. sext. imp. sept./ republica conseruata" $($ CIL $6.873=$ ILS 81). 
ferramenta de propaganda, ${ }^{15}$ já que eram amplamente utilizadas. Além disso, "as pessoas no mundo romano não contavam com os estímulos visuais com os quais contamos atualmente, por isso eles eram muito mais observados e manipulados no passado do que no presente" (GONÇALVES, 2013, p. 44).

É necessário nos debruçarmos agora sobre a forma que geralmente esta procissão triunfal se organizava, ou seja, a disposição de seus componentes. De modo geral, podese dizer que a procissão era dividida em três partes. A primeira parte incluiu os despojos de guerra transportados em espécies de carroças ou em macas portáteis (fercula); pinturas e estátuas representando o território conquistado e as batalhas travadas; coroas de ouro enviadas ao general vitorioso pelos aliados ou por povos conquistados; ${ }^{16}$ animais que deveriam ser sacrificados, trompetistas e dançarinos; e os prisioneiros de guerra, sendo que os mais importantes vinham diretamente na frente da quadriga do general (BEARD, 2007, p. 81; FAVRO, 1994, p. 154; POPKIN, 2016, p. 6).

Alguns destes componentes podem ser vistos no friso do templo de Apolo Sosiano (Figura 3), ${ }^{17}$ que retrata uma procissão triunfal. É importante destacar que, de acordo com Diane Favro (2008, p. 91), C. Sosius, cônsul em 32 a.C. e fervoroso defensor de Marco Antônio, recebeu o direito de realizar um triunfo pela derrota dos judeus. Após as comemorações, ele deu início à reconstrução do templo de Apolo Medicus. No entanto, o templo reconstruído por ele tornou-se associado não com Marco Antônio, mas com seu rival, Otaviano, pois, como aliado de Antônio, Sósio sofreu a derrota em Ácio em 31 a.C., mas, como Otaviano permitiu que ele fosse libertado, para homenagear seu novo benfeitor, Sósio reprogramou a reconstrução em andamento para exaltar a Otaviano. Assim, os relevos no edifício concluído não representam os judeus sobre os quais Sosius triunfou, mas um troféu com bárbaros do Norte, provavelmente comemorando o triunfo de Otaviano sobre a Dalmácia. O templo acabado, portanto, tornou-se um monumento triunfal a Otaviano.

\footnotetext{
${ }^{15}$ De acordo com Ana Teresa Marques Gonçalves (2013, p. 42), "o termo propaganda vem do verbo latino propagare, do substantivo propagatio, que significava ampliar, alargar, estender espaços, difundir, implantar ou prolongar, prorrogar tempos. Assim, propagator era o título de um magistrado, bem como um dos epítetos de Júpiter, aquele que amplia, que engrandece, que conquista o Império".

${ }^{16}$ De acordo com Augusto, em suas Res Gestae (XXI), ele teria mandado de volta aos Municipia e Colônias da Itália as coroas de ouros ofertadas por eles em ocasião de seu triunfo.

${ }^{17}$ O templo de Apolo in circo, construído próximo ao Circo Flamínio, ou Apolo Medicus, foi prometido em 433-432 a.C. em consequência de uma praga e foi dedicado em 431 pelo cônsul C. Iulius. O templo também é conhecido como Templo de Apolo Sosiano, pois teve sua reconstrução iniciada em 32 a.C. pelo cônsul C. Sosius, tendo sido completada por volta de 30/29 a.C. (RICHARDSON, 1992, p. 13).
} 
Figura 3 - Friso do templo de Apolo Sosiano (procissão triunfal). Museus Capitolinos

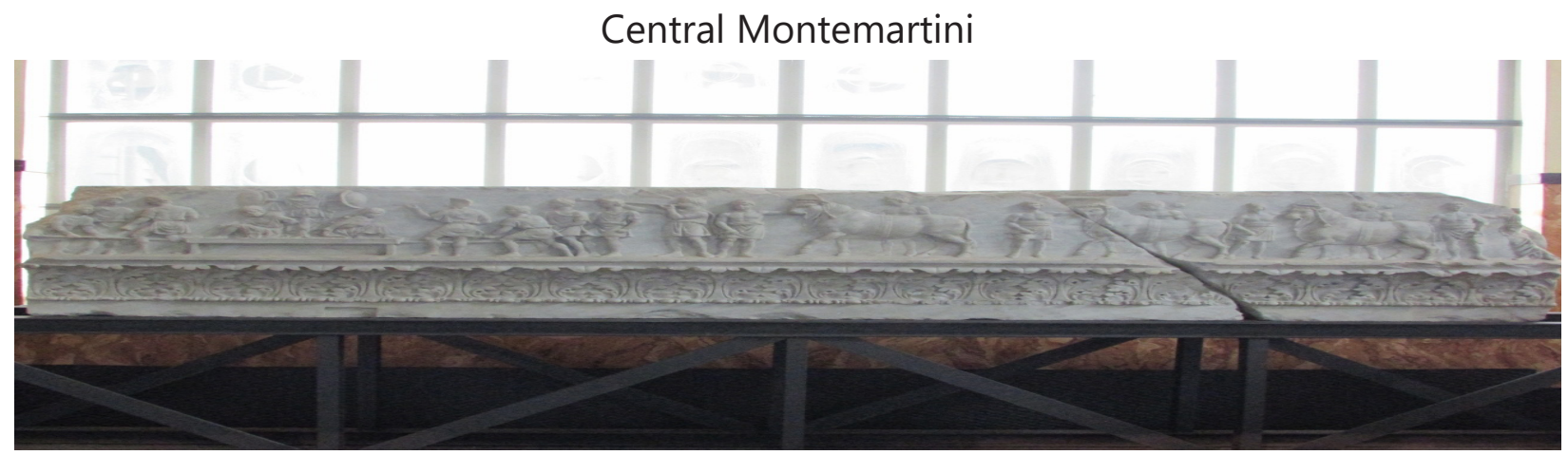

Fonte: Arquivo pessoal.

No que restou do friso, pode-se ver inicialmente os espólios de guerra sendo carregados sobre um ferculum, no qual podemos ver as armas dos derrotados dispostas como troféu de guerra ao lado de dois prisioneiros com as mãos amarradas. De acordo com Beard (2007, p. 175-176), a experiência de ver armas e prisioneiros de guerra:

Era o mais próximo que você conseguiria ter da experiência de batalha sem realmente estar lá [...]. A conversão das armas inimigas num objeto de espetáculo no território de Roma atraiu a dor desse medo, além de aumentar a humilhação dos derrotados. Desde os estandartes militares até a artilharia de ponta, seus arsenais estavam agora abertos ao olhar dos conquistadores, enquanto - como mais do que uma escultura romana retrata - os prisioneiros poderiam estar empoleirados sobre os fercula sob arrumações cuidadosas da armadura nativa deles agora reapropriada como um troféu da vitória romana.

Uma representação semelhante a este troféu de guerra com as armas dos vencidos pode ser vista em um denário cunhado no mesmo período (cerca de 29/27 a.C), que traz, no reverso, a representação centralizada deste troféu militar, disposto entre as palavras IMP CAESAR. Cruzados em sua base se encontram um leme e uma âncora, tudo isso sobre uma proa de barco. O anverso traz a efígie de Otaviano (RIC I 265a, Figura 4). Neste denário podemos ver a clara alusão à vitória naval em Ácio.

Após o ferculum com o troféu e os prisioneiros, podemos ver, no friso, a imagem dos trompetistas e os animais que seriam sacrificados. Sobre este aspecto é necessário frisar a importância da musicalidade para acompanhar a procissão triunfal, já que era uma comemoração extremamente alegre a festiva. Sobre este assunto, Beard (2007, p. 221) esclarece que "os escritores antigos às vezes imaginam trombetas 'liderando o caminho' ou 'tocando ao redor' do general, e Apiano se refere a um 'coro de tocadores de lira e flautistas' no desfile". 
Figura 4 - Moeda de Prata. Denário. RIC I 265a

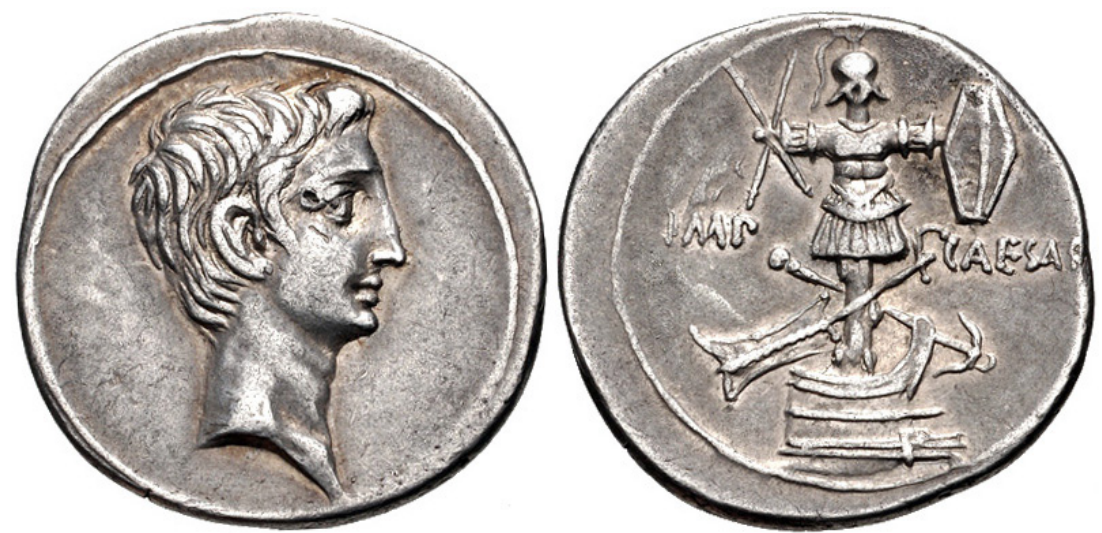

Fonte: https://www.cngcoins.com/Coin.aspx?CoinID=228607. Acesso em: 29 jul. 2017.

No que se refere aos prisioneiros mais importantes que geralmente vinham à frente da quadriga do general, no triunfo de Otaviano este lugar foi ocupado pelos filhos sobreviventes de Cleópatra, Alexandre Hélio e Cleópatra Selene. Além disso, a própria Cleópatra figuraria neste cortejo triunfal se não tivesse, como conta Plutarco (Antônio, LXXXVI), se deixado picar por uma áspide.

Como Horácio insistiu em sua "Ode a Cleópatra", escrita logo após o evento, a rainha egípcia se matou porque não estava preparada para enfrentar a humilhação de aparecer em um triunfo romano; ela preferiu furtar seu inimigo Otaviano do prazer de exibi-la pelas ruas de Roma (BEARD, 2007, p. 114).

Na impossibilidade de desfilar com Cleópatra como sua prisioneira pelas ruas de Roma, Otaviano exibe, em seu triunfo, uma réplica (simulacrum) representando a rainha do Egito. Não se sabe se esta réplica se tratava de uma pintura ou de uma escultura, mas causou impacto aos olhos de quem presenciou a procissão. Se concordarmos com a interpretação de muitos historiadores, podemos dizer que o poeta Propércio teria sido testemunha desta procissão triunfal e estaria falando sobre a réplica de Cleópatra ao falar em suas Elegias $(3,11)$ sobre a visão dos braços picados pelas serpentes sagradas e sobre o veneno percorrendo seu caminho. ${ }^{18} \mathrm{~A}$ imagem de Cleópatra junto a seus filhos como prisioneiros de guerra eram os últimos componentes desta primeira parte do triunfo.

A segunda parte foi o grupo em torno do próprio general. Ele estava em uma quadriga, às vezes decorada com ouro e marfim, e vestido com um traje elaborado, uma

\footnotetext{
${ }^{18}$ Adrian Tronson (1999, p. 171-186), em seu trabalho intitulado "What the poet saw: Octavian's Triple Triumph, 29 B.C. Jeremiah Markland's conjectures at Propertius 3.11.52-53", adotando a edição da Loeb de 1990 de George Goold, que por sua vez adota a conjectura do século XVIII de Jeremiah Markland usando 'spectasti' no lugar de 'spectavi', afirma que o poeta não teria visto os braços de Cleópatra picados por serpentes (spectavi, na $1^{\text {a }}$ pessoa do singular), mas sim que Propércio escreve que a própria Cleópatra viu isso (spectasti, na $2^{\mathrm{a}}$ pessoa do singular).
} 
coroa de louros, ${ }^{19}$ uma túnica bordada com palmas (tunica palmata) e uma luxuosa toga (uma toga púrpura, toga purpurea, ou uma toga decorada com estrelas douradas, toga picta); em sua mão esquerda, segurava um cetro de marfim e, na direita, um ramo de louro. Atrás dele, na quadriga estaria um escravo, segurando uma coroa de ouro sobre sua cabeça e sussurrando para ele durante toda a procissão: "Olhe para trás. Lembre-se que você é um homem". Atrás da quadriga vinham seus principais oficiais e cidadãos romanos que ele libertou (BEARD, 2007, p. 81; FAVRO, 1994, p. 154; POPKIN, 2016, p. 6).

A quadriga, um majestoso carro puxado por quatro cavalos, era um dos componentes mais importantes e mais característicos do triunfo, sem a qual não teria triunfo. Sua presença é tão fundamental e indispensável na procissão triunfal que é um dos aspectos que diferem um triunfo das ovationes, por exemplo, já que, nas ovationes, uma espécie de triunfo menor, o general andava a pé ou montado num cavalo e ao invés de usar uma coroa de louros, usava uma feita de murta. Tanto a quadriga triunfal quanto a coroa de louros usada pelo triunfador possuíam, neste contexto, estreita ligação com a vitória. Uma representação disso pode ser vista em um denário cunhado neste período (cerca de 29/27 a.C), que traz, no anverso, a imagem da Vitória, em pé sobre a proa de um barco, trazendo, em sua mão direita, uma grinalda e sobre o ombro esquerdo um ramo de palmeira. No reverso, encontra-se a imagem de Otaviano em uma esplêndida quadriga triunfal, cujos painéis dianteiro e laterais são adornados com figuras. Ele está segurando as rédeas na mão esquerda e o ramo de louro na direita. Abaixo se encontra a inscrição IMP CAESAR (RIC I 264, Figura 5). ${ }^{20}$

Figura 5 - Moeda de Prata. Denário. RIC I 264.
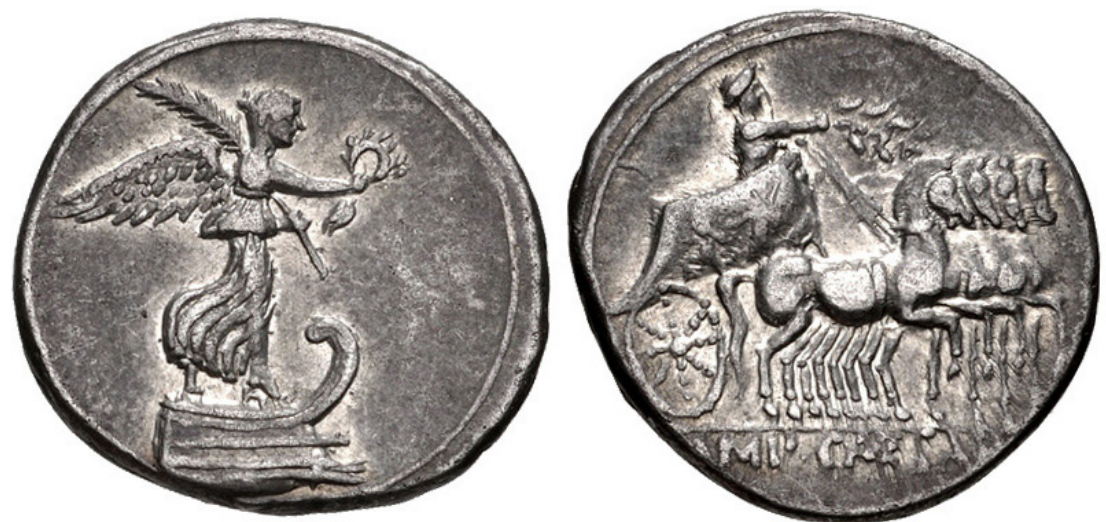

Fonte: https://www.cngcoins.com/Coin.aspx?CoinID=179245. Acesso em: 29 jul. 2017.

\footnotetext{
${ }^{19}$ A partir de 36 a.C. Otaviano recebeu o direito de usar a coroa de louro em todos os momentos e, em 29 a.C., o direito de usar a coroa de ouro e talvez o resto da veste triunfal em todas as festas (LANGE, 2009, p. 130).

20 De acordo com as informações disponíveis no site do Classical Numismatic Group, parece provável que este seja o primeiro tipo a ser emitido na série IMP CAESAR, uma vez que substitui um outro denário idêntico com a legenda CAESAR DIVI F (RIC, I, 263). Disponível em: www.cngcoins.com/Coin.aspx?CoinID=22251. Acesso em 28 jul. 2017.
} 
No que se refere à possível presença de um escravo atrás de Otaviano, segurando uma coroa de ouro sobre sua cabeça e sussurrando para ele: "Olhe para trás. Lembrese que você é um homem", devemos dizer que tal quadro é o resultado da junção de diferentes vertentes de evidências, pois nenhum escritor antigo apresenta essa imagem completa. Alguns falam sobre a presença do escravo, mas não mencionam o que o escravo falava, já outros falam sobre o conselho ao triunfador, para não se esquecer de sua mortalidade, mas sem mencionar a presença de um escravo (BEARD, 2007, p. 8587). Seja como for, as evidências materiais nos ajudam a inferir sobre a presença de um escravo, atrás de Otaviano, segurando a coroa de ouro sobre sua cabeça ao longo da procissão triunfal, pois podemos ver a representação desta cena em uma das peças do tesouro de Boscoreale.

Trata-se de um escifo (skyphos), ${ }_{1}^{21}$ uma taça de vinho com duas alças, feito em prata, retratando, em sua decoração, o triunfo de Tibério. Em um dos lados pode-se ver o futuro Imperador na quadriga, segurando um ramo de louro em uma mão e o cetro na outra; atrás dele um escravo segura uma grinalda ou uma coroa sobre sua cabeça. A data exata da peça depende de qual dos dois triunfos de Tibério está representado: 7 a.C. ou 12 d.C. (Figura 6). Apesar de retratar o triunfo de Tibério, podemos deduzir que este deve ter acontecido no triunfo de Otaviano.

Figura 6 - Escifo de Boscoreale

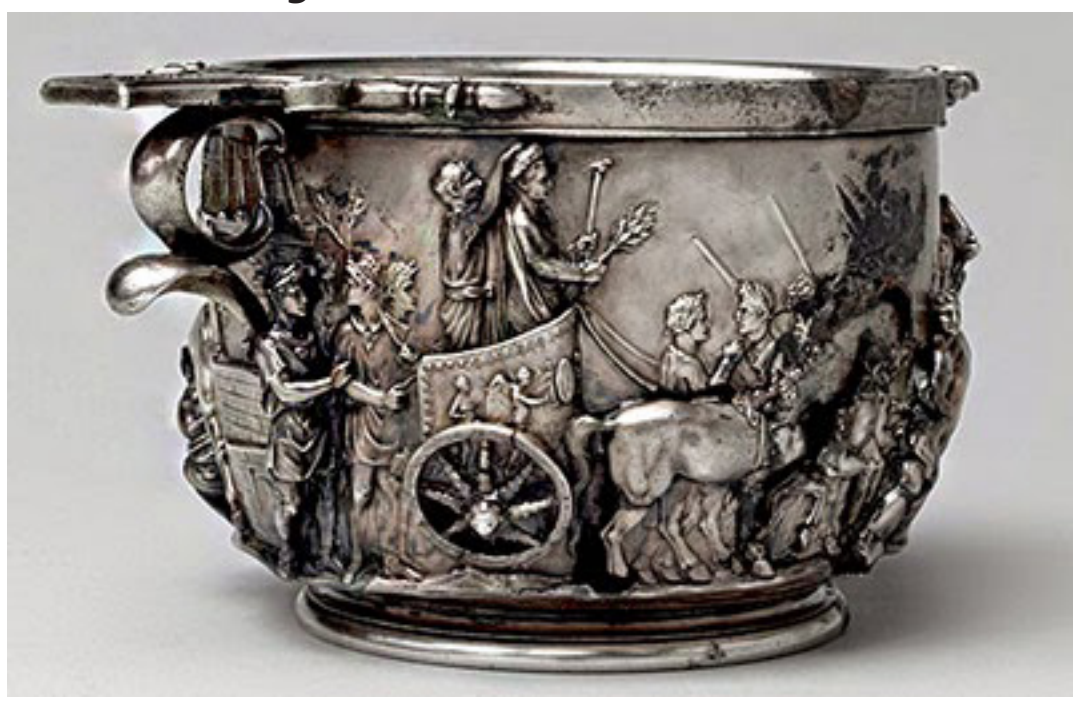

Fonte: https://br.pinterest.com/pin/524669425319762969. Acesso em: 29 jul. 2017.

Por meio de Suetônio (De Vita Caesarum, Tiberius, VI. 4), sabemos que, acompanhando a quadriga de Otaviano, estavam os jovens Tibério e Marcelo, a cavalo.

\footnotetext{
${ }^{21}$ Atualmente a peça se encontra no Museu do Louvre.
} 
Tibério estava à esquerda e Marcelo à direita de Otaviano. No fim desta segunda parte do triunfo estavam as pessoas que vinham imediatamente atrás da quadriga. Sobre este aspecto, Dion Cássio (Hist. Rom., LI, 21) afirma que, em seu triunfo, Otaviano teria realizado uma inovação, algo contrário ao precedente, pois, segundo Dion Cássio, embora os magistrados costumassem andar em frente à quadriga triunfal, enquanto os senadores que haviam participado da vitória caminhavam atrás, Otaviano permitiu que seu colega de consulado e os outros magistrados seguissem atrás dele.

Sobre essa inovação de Otaviano há opiniões diferentes entre os historiadores. Alguns, como Anthony Everitt (2008, p. 243), veem esta atitude do imperator como um reflexo do domínio de Otaviano, "uma clara demonstração de seu predomínio político". Já outros, como Mary Beard (2007, p. 240), acreditam que Dion Cássio quis dizer justamente o contrário, pois dizer que Otaviano permitiu que eles seguissem atrás dele, implicava dizer que era uma honra andar atrás da quadriga, ao invés de na frente. Para Tarpin (2009, p. 140), o juramento dos mais de 700 senadores que, segundo Augusto (Res Gestae Diui Augusti, XXV), lutaram sob suas insígnias, colocou-os na posição de soldados e não mais representantes da autoridade civil que acolhem o vencedor, de modo que a exceção notada por Dion é justificada por uma situação muito particular e, por isso, contrária à prática republicana.

A parte final do triunfo foi composta pelos soldados vitoriosos, usando grinaldas de louro e cantando o grito triunfal ritual de "io triumpe", intercalado com canções sobre o próprio general. Quando chegaram ao pé do Capitólio, alguns dos principais prisioneiros poderiam ter sido retirados para execução. $O$ resto da procissão abriu caminho até o Templo de Júpiter (BEARD, 2007, p. 82; FAVRO, 1994, p. 154; POPKIN, 2016, p. 7). A grandiosidade e extravagância desta procissão triunfal deve ter sido impressionante, com toda sua riqueza de detalhes e de estímulos visuais e auditivos.

O reluzente vestuário branco dos espectadores contrastou grandemente com a vestimenta colorida das figuras na parada, visualmente distinguindo os dois grupos. Acima das cabeças da multidão, decorações temporárias embelezavam as construções ao longo da rota, separando-as de outras estruturas em Roma (FAVRO, 1994, p. 157).

Segundo Tonio Hölscher (2006, p. 37), o triunfo foi a maneira melhor e mais imediata de envolver os cidadãos nos resultados da guerra, fazendo-os participar pessoalmente nos rituais e celebração da vitória. Além disso, a riqueza trazida por Otaviano para Roma, principalmente aquelas vindas do Egito, foi algo impressionante, não só no dia do triunfo como depois, por exemplo, quando chegaram os obeliscos que Otaviano mandou trazer 
do Egito e dispôs em diferentes lugares em Roma. ${ }^{22} \mathrm{O}$ magnífico e notável feito de derrotar o Egito, um dos "celeiros" do Mundo Antigo, e torná-lo cativo de Roma foi propagado por diversos meios, ressaltando o feito e o nome de Otaviano, o Imperator Caesar, como pode ser visto no denário cunhado no período (29-27 a.C.), que possui, no reverso, o desenho de um crocodilo, representando o Egito, junto com a inscrição AEGYPTO CAPTA. No anverso, há a efígie de Otaviano com um lituus atrás, com a inscrição CAESAR CONS VI (cônsul pela sexta vez), (RIC I 275a. Figura 7).

Figura 7 - Moeda de Prata. Denário. RIC I 275a
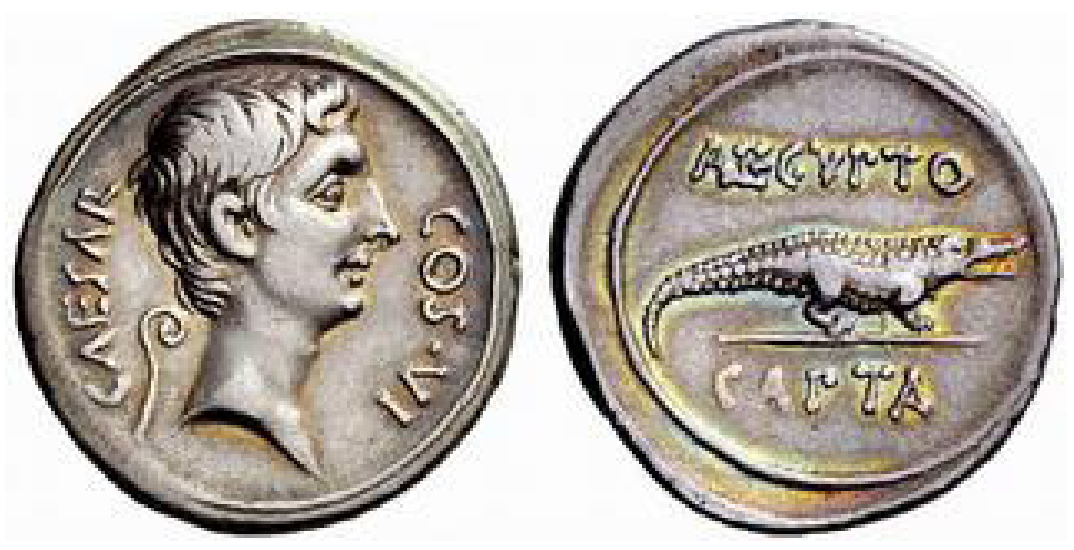

Fonte: http://www.ancientcoins.ca/RIC/. Acesso em: 29 jul. 2017.

Não apenas a riqueza trazida com o triunfo era importante para a sociedade de então, como também toda a carga simbólica que ele agregava. Uma delas é concernente à derrota do Egito, propagada por Otaviano e seu grupo de apoio como o lugar da extravagância, barbárie e exotismo, uma ameaça oriental aos respeitáveis costumes e tradições romanas; outra ainda mais importante diz respeito ao fim das guerras civis, período conturbado, de instabilidade, insegurança e de incerteza quanto ao futuro. A vitória e o triunfo de Otaviano eram sinônimos de esperança renovada, o prenúncio de paz, prosperidade e estabilidade. Tal vitória seria lembrada em muitos monumentos ao longo de seu governo.

Mas o triunfo desempenhava também um importante papel didático, pois, de acordo com Favro (1994, p. 154):

Através da exibição dos espólios, cidadãos romanos aprendiam não apenas sobre as proezas de seus exércitos e generais, mais também sobre o povo, arte,

\footnotetext{
${ }^{22}$ Augusto trouxe dois obeliscos de Heliópolis, em 10 a.C. Um foi colocado na espinha do Circus Maximus como um monumento à conquista do Egito. O outro serviu de gnomon (a haste vertical que permite a formação da sombra na superfície do relógio solar) para seu grande relógio solar, o Horologium.
} 
arquitetura e fauna dos adversários conquistados. Juntamente com o general e sua turbulenta tropa veio uma panóplia de exibições.

Além disso, a importância do triunfo, como enfatiza Beard (2007, p. 160-161), não estava somente no impacto especificamente financeiro, visual ou artístico da cerimônia, mas sua importância também estava na cultura do imperialismo romano e no imaginário dos romanos. A procissão serviu de microcosmos dos próprios processos de expansão imperial. A estranheza flagrante de alguns dos despojos da guerra, juntamente com as várias representações da conquista, delineou uma imagem nova e expansível do território imperial diante dos olhos dos espectadores. A procissão triunfal trouxe o Orbs para dentro dos muros da Vrbs. Cada vez mais Roma se tornava a capital do mundo conhecido.

O ponto óbvio é que o triunfo e seus cativos representavam uma realização física do Império e do imperialismo. Além da imagem dos conflitos romanos com a monarquia, a procissão (ou as versões escritas da procissão) justificou a própria ideia de expansão territorial romana, sua conquista do globo. A estranheza exótica dos prisioneiros, no coração da capital imperial, mostrava para as pessoas que estavam assistindo a procissão (ou lendo sobre ela, ou ouvindo contar sobre ela, mais tarde), a expressão mais tangível que você poderia desejar do poder mundial de Roma (BEARD, 2007, p. 123).

Esta demonstração de poder e riqueza era também uma demonstração de pietas, $^{23}$ já que o objetivo final da procissão era o Templo de Júpiter, no alto do monte Capitólio. Lá os animais eram sacrificados ao deus e outras oferendas foram feitas pelo general.

Como defende Diane Favro (1994, p. 155), apaziguar e honrar os deuses era um dos propósitos da cerimônia triunfal; e a natureza expiatória do evento estava evidente em cada fase. As atividades no monte Capitolino focaram no propósito religioso do triunfo. $\mathrm{O}$ triunfador prosseguia a pé, subindo o íngreme Clivus Capitolinus para o templo de Jupiter Optimus Maximus, onde ele solenemente sacrificava um boi branco e deixava um ramo de louro e a coroa junto à estátua de Júpiter; próximo dali, no templo menor, ele oferecia alguns espólios de guerra selecionados para Jupiter Feretrius (FAVRO, 1994, p. 155).

O triunfo acabava com um banquete para o triunfador e o Senado, e se Otaviano tiver seguido o exemplo de César, em seu triunfo de 46 a.C., além do banquete com o Senado, ele deve ter oferecido um grandioso banquete público para milhares de pessoas, embora não possamos afirmar se isso aconteceu. Seja como for, com o banquete estava terminado o triunfo. Findava-se um ciclo, pois "antes de deixar Roma em sua campanha, o

\footnotetext{
${ }^{23}$ Segundo John Scheid (2007, p. 177), "pietas era uma correta relação social com os deuses; significava dar a eles as honras devidas à sua posição e associá-los com o governo da Res Publica, como concidadãos, ou melhor, como bons patroni da cidade".
} 
general tinha sacrificado para Júpiter no mesmo lugar; retornando vitorioso, ele completou o ciclo" (FAVRO, 1994, p. 156).

Em agosto de 29 a.C., quem chegasse a Roma se encantaria com a movimentação e decoração da cidade para o ritual que representava o fim deste ciclo realizado por Otaviano e suas tropas. O triunfo de Otaviano deixava uma marca indelével na memória romana, seja por meio de relatos, de moedas, da literatura, da arte ou da arquitetura. Foram dias de glória que marcaram o retorno do general vitorioso, que ficaria conhecido como aquele que pôs fim às guerras civis. Tais festividades marcaram o início de um novo tempo em Roma, cuja nova forma de governo recebeu o nome de Principado.

Percebemos, com isso, que o triplo triunfo de Otaviano foi realizado de modo a se inscrever na memória romana, como a grande comemoração para um feito monumental. Mas além desta grande comemoração ocorrida em 29 a.C., Otaviano, ao longo de todo o seu governo, se utilizou da imagem de grande triunfador e da temática triunfal como estratégia política e de modo a legitimar seu poder.

Com relação à sua imagem de triunfador, é importante ressaltar que Otaviano manipulou cerimônias políticas e explorou a mídia visual de forma a monopolizar esta. Paradoxalmente, uma das formas que ele utilizou para isso foi evitando procissões triunfais depois de seu magnífico triplo triunfo em 29 a.C., além de conseguir restringir os triunfos de outros generais. Ao mesmo tempo, ele fez pleno uso de outras cerimônias, honras, moedas e monumentos que proclamavam sua associação pessoal e contínua com o papel de triunfador (HICKSON, 1991, p. 124).

Tal política foi de extrema importância, haja vista que, no que se refere às vitórias militares, o então Otaviano tinha rivais que poderiam competir com ele pela proeminência em Roma, como nos lembra Rosalinde Kearsley (2009, p. 148-156), ao afirmar que Licínio Crasso, cônsul em 30 a.C., caracterizou-se como um potencial rival e o mais indesejado à reivindicação de Otaviano pela liderança militar de Roma após 31 a.C., pois, em sua campanha militar como governador da Macedônia, Crasso se distinguiu entre os comandantes romanos de uma maneira extremamente rara, já que ele conseguiu capturar a armadura do rei inimigo em combate singular. Segundo esta autora, para Otaviano, essa conquista deve ter representado o surgimento de uma ameaça perturbadora para seu próprio desejo de supremacia contínua. Ele não podia permitir que Crasso o superasse devido à importância que a dedicação dos spolia opima tinha no imaginário da época, já que a façanha dos spolia opima tinha sido alcançada por apenas três romanos antes de 29 a.C., sendo que Rômulo foi o primeiro. Isso deve ter marcado Crasso como o oponente mais perigoso de Otaviano, de modo que Crasso realizou o triunfo, mas não pôde dedicar os spolia opima. 
De acordo com Frances V. Hickson (1991, p. 127-128), a vitória para a qual Crasso recebeu seu triunfo provavelmente desempenhou um papel muito importante na decisão de Otaviano de buscar uma política mais restritiva em relação aos triunfos. Certamente, ele não gostou de oferecer a um líder militar rival uma oportunidade tão extraordinária de atrair o favor popular em um momento em que ainda estava consolidando seu próprio poder. Para este autor, a experiência com Crasso enfatizou a necessidade de lidar com potenciais rivais que ainda ameaçavam o poder do novo regime, levando Otaviano a estabelecer políticas mais restritivas em relação aos triunfos, de modo que, em 27 a.C., ele realizou uma reorganização da administração provincial, na qual ele nomeou os legati pro praetore para governar a maioria das províncias onde as campanhas militares eram comuns. Esses legati lutavam sob os auspícios do então Augusto, e como não possuíam auspicia independente, nenhum desses generais recebeu triunfos por suas vitórias. Nas restantes províncias, o Senado continuou a nomear procônsules possuindo auspicia sua e, portanto, o direito de triunfar. Mas como este autor nos lembra, com exceção da África e da Macedônia, essas províncias não precisavam de presença militar significativa e ofereceu poucas oportunidades para vitórias dignas de triunfos.

Percebemos, com isso, como Augusto se utilizou da imagem de triunfador e de seu papel de proporcionar grandes obras arquitetônicas ao povo para construir sua imagem, deixando seu nome, seus feitos e suas obras arquitetônicas inscritos na memória das futuras gerações.

Ao celebrar apenas o triplo triunfo, Augusto centrou a propaganda triunfal do Principado nesse evento extraordinário. $O$ número três é significativo. Augusto colocou-se firmemente dentro da tradição republicana, recusando-se a aceitar novos triunfos. De acordo com os fasti triumphales, apenas três homens haviam excedido esse número; todos eram ditadores. Claramente, essa não era uma imagem que Augusto desejaria promover. Ao limitar-se a três triunfos, no entanto, Augusto identificou-se com um líder cuja imagem ele achou agradável. Os três primeiros triunfos listados nos fasti triumphales pertencem a Rômulo, o primus conditor urbis. Das vitórias de Augusto, evidências monumentais e numismáticas indicam que Ácio foi o principal assunto das imagens de triunfo. Esta foi a vitória pela qual, como a propaganda imperial sublinhou, Augusto conservara a República. Ao não celebrar triunfos repetidos por vitórias menores ou vitórias em que ele desempenhou um papel menor, Augusto protegeu sua imagem como triumphator par excellence (HICKSON, 1991, p. 137).

O triplo triunfo de Otaviano, ocorrido em 29 a.C., foi, portanto, um marco na carreira política daquele que entraria para a história como o primeiro imperador romano. Ao comemorar suas vitórias militares, dentre elas aquela contra Cleópatra e Marco Antônio, vistos na época como uma ameaça oriental ao poder de Roma, o triplo triunfo desempenhou um importante papel no imaginário daquele período, simbolizando o fim 
de tempos de guerra e a promessa de tempos de paz e prosperidade, o que passou a ser amplamente utilizado e propagado por Augusto ao longo de seu governo.

\section{Referências}

\section{Documentação textual}

AUGUSTUS. Res Gestae Divi Augusti. English translation by Frederick W. Shipley. London: Harvard University Press, 1961.

DIO CASSIUS. Dio's Roman history. English translation by Earnest Cary. Cambridge: Harvard University Press, 1924.

DIONYSIUS OF HALICARNASSUS. The Roman antiquities. English translation by Earnest Carry. London: William Heinemann, 1960.

FLAVIUS JOSEPHUS. The Wars of the Jews. English translation by William Whiston. Auburn: John E. Beardsley, 1895.

PLUTARCH. The Life of Antony. In: PLUTARCH. The Parallel Lives. English translation by. Bernadotte Perrin. London: William Heinemann, 1919.

PROPERTIUS. Elegies. Editing and translation by G. P. Gold. Cambridge: Harvard University Press, 1990.

SUETONIUS. Life of Augustus. In: SUETONIUS. Lives of the Caesars. English translation by J. C. Rolfe. London: William Heinemann, 1914.

TITUS LIVIUS. History of Rome. English translation by Canon Roberts. London: Everyman's Library Classical, 1905.

\section{Obras de referência}

RICHARDSON, L. A New topographical dictionary of ancient Rome. London: Johns Hopkins University Press, 1992.

\section{Obras de apoio}

BEARD, M. The Roman Triumph. Cambridge: Harvard University Press, 2007.

EVERITT, A. Augusto: el primer emperador. Barcelona: Ariel, 2008.

FAVRO, D. The street triumphant: the urban impact of Roman triumphal parades. In: ÇELIK, Z.; FAVRO, D.; INGERSOLL, R. (Ed.). Streets: critical perspectives on public space. Los Angeles: University of California Press, 1994, p. 151-164. 
FAVRO, D. The urban image of Augustan Rome. Los Angeles: Cambridge University Press, 2008.

FAVRO, D.; JOHANSON, C. Death in motion: funeral processions in the Roman Forum. Journal of the Society of Architectural Historians, v. 69, n. 1, p. 12-37, 2010.

GONÇALVES, A. T. M. A noção de propaganda e sua aplicação nos estudos clássicos: o caso dos imperadores romanos Septímio Severo e Caracala. Jundiaí: Paco, 2013.

HICKSON, F. V. Augustus "Triumphator": manipulation of the triumphal theme in the political program of Augustus. Latomus, t. 50, f. 1, p. 124-138, 1991.

HOLLAND, L. B. The triple arch of Augustus. American Journal of Archaeology, v. 50, n. 1, p. 52-59, 1946.

HÖLSCHER, T. The transformation of victory into power: from event to structure. In: DILLON, S.; WELCH, K. E. (Ed.). Representations of war in Ancient Rome. Cambridge: Cambridge University Press, 2006, p. 27-48.

HOPE, V. The city of Rome: capital and symbol. In: HUSKINSON, J. (Ed.). Experiencing Rome: culture, identity and power in the Roman Empire. New York: Routledge, 2005, p. 63-93. KEARSLEY, R. Octavian and Augury: the years 30-27 B.C. The Classical Quarterly, v. 59, n. 1, p. 147-166, 2009.

KLEINER, F. The study of Roman triumphal and honorary arches 50 years after Kähler. Journal of Roman Archaeology, v. 2, p. 195-206, 1989.

LANGE, C. H. Res Publica Constituta: Actium, Apollo and the accomplishment of the Triumviral Assignment. Leiden: Brill, 2009.

MARTINS, P. Imagem e poder: considerações sobre a representação de Otávio Augusto. São Paulo: Edusp, 2011.

POPKIN, M. L. The architecture of the Roman Triumph: monuments, memory and identity. New York: Cambridge University Press, 2016.

SCHEID, J. Augustus and Roman religion. In: GALINSKY, K. (Ed.). The Age of Augustus. New York: Cambridge University Press, 2007, p. 175-193.

SILVA, C. F. P. A construção da imagem de Otávio, Cleópatra e Marco Antônio entre moedas e poemas (44 a 27 a.C.). 2014. 189 f. Dissertação (Mestrado em História) - Programa de Pós-Graduação em História Social das Relações Políticas, Universidade Federal do Espírito Santo, Vitória, 2014.

TARPIN, M. Le triomphe d'Auguste: héritage de la République ou révolution?. In: HURLET, F.; MINEO, B. (Dir.) Le Principat d'Auguste: realités et répresentations du pouvoir autour de la Res publica restituta. Rennes: Presses Universitaires de Rennes, 2009, p. 129-142.

TRONSON, A. What the poet saw: Octavian's Triple Triumph, 29 B.C. Jeremiah Markland's conjectures at Propertius 3.11.52-53. Acta Classica, v. 42, p. 171-186, 1999. 